\title{
Genetic group and heterosis on morphometric measurements during the growth of male beef cattle
}

\section{Grupo genético e heterose sobre medidas morfométricas durante o crescimento de bovinos de corte machos}

\author{
Ricardo Zambarda Vaz; ;oão Restle ${ }^{2 *}$; Paulo Santana Pacheco ${ }^{3}$; Fabiano Nunes Vaz \\ Luiz Danilo Muehlmann; ${ }^{5}$ Dari Celestino Alves Filho ${ }^{3}$; Régis Luis Missio ${ }^{6}$; \\ Marcia Bitencourt Vaz ${ }^{7}$
}

\begin{abstract}
In the present study, the effects of genetic group and heterosis on body measurements of purebreds (Charolais - C and Nellore - N), first-generation crossbreds (G1) $\left(1 / 2 \mathrm{C}^{1} \frac{1}{2} \mathrm{~N}\right.$ and $1 / 2 \mathrm{~N} \quad 1 / 2 \mathrm{C}$ ), and second-generation crossbreds (G2) $\left(3 / 4 \mathrm{C} 1 / 4^{1 / 2}\right.$ and $\left.3 / 4 \mathrm{~N}^{1 / 4} \mathrm{C}\right)$ males from rotational crossbreeding were evaluated at $8,12,18$, and 24 months of age. Among the purebreds, the Nellore displayed greater rump height than the Charolais. The Charolais had greater thoracic perimeter than the Nellore, however this difference decreased gradually with advancing age, being equal between the two genetic groups at 24 months. For width of the rump, ischial opening and thoracic perimeter crossbred animals showed higher values than the purebred animals at all ages, but less pronounced at eight months of age. For all morphometric measurements, with exception of rump height, the differences of crossbreds males in relation to the purebreds, were more evident in relation to the Nellore. Heterosis was significant for morphometric measurements in male beef cattle. Morphometric measurements showed high correlation with each other and with body weight, thereby indicating that they are good indicators of body development.
\end{abstract}

Key words: Bos taurus taurus. Bos taurus indicus. Charolais. Crosbreeding. Morphometric measurements. Nellore.

\section{Resumo}

Foram avaliados os efeitos de grupo genético e heterose nas medidas corporais de machos puros (Charolês - C e Nelore - N); mestiços de primeira geração (G1) $\left(1 / 2 \mathrm{C}^{1} 1 / 2 \mathrm{~N}\right.$ e $1 / 2 \mathrm{~N} 1 / 2 \mathrm{C}$ ); e mestiços

\footnotetext{
${ }^{1}$ Prof., Departamento de Zootecnia, Faculdade de Agronomia, Universidade Federal de Pelotas, UFPEL, Pelotas, RS, Brasil. E-mail: rzvaz@terra.com.br

${ }^{2}$ Prof., Programa de Pós-Graduação em Zootecnia, Universidade Federal de Goiás, UFG, Goiânia, GO, Brasil. E-mail: jorestle@ terra.com.br

${ }^{3}$ Profs., Departamento de Zootecnia, Universidade Federal de Santa Maria, UFSM, Santa Maria, RS, Brasil. E-mail: paulosantanapacheco@hotmail.com; darialvesfilho@hotmail.com

${ }^{4}$ Prof., Departamento de Educação Agrícola e Extensão Rural, UFSM, Santa Maria, RS, Brasil. E-mail: fabianonunesvaz@ gmail.com

${ }^{5}$ Pesquisador, Instituto EMATER, Curitiba, PR, Brasil. E-mail: danilo@emater.pr.gov.br

${ }^{6}$ Prof., Departamento de Zootecnia, Universidade Tecnológica Federal do Paraná, UTFPR, Pato Branco, PR, Brasil. E-mail: regisluismissio@gmail.com

7 Discente do Curso de Mestrado, Programa de Pós-Graduação em Zootecnia, UFPEL, Pelotas, RS, Brasil. E-mail: mbvaz@ hotmail.com

* Author for correspondence
} 
de segunda geração $(\mathrm{G} 2)\left(3 / 4 \mathrm{C} 1 / 4 \mathrm{Ne}^{3 / 4} \mathrm{~N} \mathrm{1/4} \mathrm{C}\right)$ oriundos de cruzamento rotativo. Os animais foram avaliados aos 8, 12, 18 e 24 meses de idade. Entre as raças puras, o Nelore apresentou maior altura da garupa do que o Charolês em todas idades. O Charolês foi superior ao Nelore em perímetro torácico, porém esta diferença decresceu gradativamente com o avanço da idade, sendo igual entre os dois grupos genéticos aos 24 meses. Para largura da garupa, abertura isquiática e perímetro torácico, os animais mestiços apresentaram valores médios mais elevados do que os machos puros, em todas as idades, porém menos acentuados aos oito meses de idade. Para as medidas avaliadas, com exceção para altura de garupa, as diferenças dos mestiços frente aos puros, foram mais evidentes em relação ao Nelore. A heterose se mostrou significativa para medidas morfométricas de bovinos de corte machos. As medidas corporais possuem alta correlação entre elas e com o peso corporal, sendo bons indicadores de desenvolvimento corporal.

Palavras-chave: Bos taurus taurus. Bos taurus indicus. Charolês. Cruzamento. Medidas morfometricas. Nelore.

\section{Introduction}

The body growth of animals is typically assessed by measuring body weight without association with conformation measurements, however, given the interaction between these two variables, collectively they would better represent the growth of individuals (REZENDE et al., 2011). Evaluating an animal by its body weight alone might be considered rather imprecise (PEREIRA et al., 2010), because several environmental factors such as nutrition, management, and physiological and/or pathological factors may affect animal performance. In this regard, body measurements are less influenced by these factors, and their evaluation as a unit is highly recommended (VIEIRA et al., 2004; PACHECO et al., 2008).

Although subjective, the evaluation of body conformation is a method of quantifying animal development qualitatively. However, if evaluated objectively, i.e., by recording body measurements, body conformation can be quantified more efficiently and in association with animal weight, thereby determining the most productive animals.

The identification of high and positive genetic correlations between body measurements and the weight of animals having consequently an increase in efficiency of production can help producers choose a trait of greater heritability, thus producing animals that are better adapted to the production system (PACHECO et al., 2008; REZENDE et al.,
2011). This also helps with the judging of show animals, which will be the sires/dams of commercial herds, because through body weight measurements at different life stages, heavier and more demanding animals are automatically selected. Analyzing animal maturity, Rocha et al. (2003) recommended evaluating body weight together with a linear measurement such as rump height to obtain better precision in results.

It is important to determine the pattern of measurements in the different animal biotypes, as well as the behavior of the heterosis of these traits, to help direct crossbreeding practices within commercial herds (MENEZES et al., 2008). The objectives of the present study were to examine the effects of the mating system, the genetic groups within each mating system, and their interactions on the morphometric development of male beef cattle from 8 to 24 months of age, and to measure the resulting heterosis.

\section{Material and Methods}

The study was conducted in the Beef Cattle Unit of the Department of Animal Science at the Federal University of Santa Maria, located in Santa Maria, Rio Grande do Sul, Brazil. We used a total of 78 young males, (Charolais - $\mathrm{C}$ and Nellore - N) and crossbreds from the first (G1) $(1 / 2$ C $1 / 2$ $\mathrm{N}$ and $1 / 2 \mathrm{~N} 1 / 2 \mathrm{C})$ and second $(\mathrm{G} 2)(3 / 4 \mathrm{C} 1 / 4 \mathrm{~N}$ and $3 / 4 \mathrm{~N}^{1 / 4} \mathrm{C}$ ) generations of the alternate rotational 
crossbreeding of the Charolais and Nellore breeds, born during the same calving season and always maintained under the same nutritional and sanitary management conditions. The Charolais and Nellore sires were the same for purebreds and G1 and G2. The animals were originated from a reproductive management program consisting of 45 days of artificial insemination and subsequent natural breeding using clean up bulls for another 45 days. Males were generated from the semen of six bulls of each breed, and from four clean up bulls of each breed.

The animals were early weaned at three months of age. Measurements began when the animals were, on average, 8 months of age. Evaluations occurred until 24 months, when the animals were slaughtered. From weaning until 8 months of age, animals were maintained on a millet pasture
(Pennisetum purpureum). From 8 until 12 months of age, they were fed in a feedlot. From 12 until 20 months of age, they were kept in native pasture and from 20 to 24 months they were feedlot finished.

Body weight and body measurements were collected at $8,12,18$, and 24 months of age. The following measurements were obtained: rump height, corresponding to the distance from the top of the sacrum to the soil surface, measured using a set-square; thoracic perimeter, obtained using a tape measure; and width of the ischium or ischial opening measured as the distance between the edges of the ischial bones and rump width, determined as the distance between the edges of the ilium bones, measured from the rear and upper regions of the hip, respectively, using a tape measure. Body measurements and body weights (Table 1) were taken on the same occasion.

Table 1. Means, standard-errors and heterosis of weight $(\mathrm{kg})$ of males at different phases of development, according to genetic group.

\begin{tabular}{|c|c|c|c|c|c|}
\hline \multirow{2}{*}{$\begin{array}{c}\text { Genetic } \\
\text { Composition }\end{array}$} & \multicolumn{4}{|c|}{ Animals age, months } & \multirow{2}{*}{ Increase } \\
\hline & 8 & 12 & 18 & 24 & \\
\hline Charolais (C) & $147.8 \pm 10.1$ & $256.3 \pm 10.1$ & $267.0 \pm 10.1$ & $396.6 \pm 10.1$ & $248.9 \pm 10.4^{\mathrm{a}}$ \\
\hline Nellore (N) & $110.2 \pm 11.0$ & $183.3 \pm 11.0$ & $228.5 \pm 11.4$ & $346.1 \pm 11.4$ & $235.9 \pm 11.8^{\mathrm{a}}$ \\
\hline Straigthbreeds means & $129.0 \pm 10.3$ & $219.8 \pm 10.4$ & $247.8 \pm 10.5$ & $371.4 \pm 10.6$ & $242.4 \pm 7.8^{\mathrm{C}}$ \\
\hline $1 / 2 \mathrm{C}^{1} / 2 \mathrm{~N}$ & $122.9 \pm 15.4$ & $208.9 \pm 15.4$ & $278.4 \pm 16.4$ & $436.7 \pm 15.4$ & $313.8 \pm 15.4^{\mathrm{a}}$ \\
\hline $1 / 2 \mathrm{~N}^{1} / 2 \mathrm{C}$ & $139.6 \pm 12.8$ & $242.8 \pm 12.8$ & $298.0 \pm 12.8$ & $437.6 \pm 12.8$ & $298.0 \pm 12.7^{\mathrm{a}}$ \\
\hline G1 means & $131.3 \pm 14.1$ & $225.9 \pm 14.2$ & $288.2 \pm 14.6$ & $437.2 \pm 14.7$ & $305.9 \pm 10.3^{A}$ \\
\hline $3 / 4 \mathrm{C}^{1 / 4} \mathrm{~N}$ & $160.8 \pm 11.2$ & $240.6 \pm 11.2$ & $290.7 \pm 11.6$ & $425.9 \pm 11.2$ & $265.1 \pm 11.1^{\mathrm{a}}$ \\
\hline $3 / 4 \mathrm{~N}^{1 / 4} \mathrm{C}$ & $137.9 \pm 14.6$ & $209.8 \pm 15.4$ & $286.7 \pm 14.6$ & $413.8 \pm 14.6$ & $275.9 \pm 14.6^{\mathrm{a}}$ \\
\hline G2 means & $149.4 \pm 13.3$ & $225.2 \pm 13.8$ & $288.7 \pm 13.4$ & $419.9 \pm 13.1$ & $270.5 \pm 9.2^{\mathrm{B}}$ \\
\hline \multicolumn{6}{|l|}{ Heterosis, \% } \\
\hline G1 & 1.8 & 2.8 & 16.3 & 17.7 & \\
\hline $\mathrm{G} 2$ & 15.8 & 2.4 & 16.5 & 13.1 & \\
\hline Retained heterosis, $\%$ & 8.8 & 2.6 & 16.4 & 15.4 & \\
\hline \multicolumn{6}{|c|}{ Crossbreds difference, vs } \\
\hline $\mathrm{C}(\%)$ & -5.1 & -12.0 & 8.0 & 8.1 & \\
\hline N (\%) & 27.4 & 23.1 & 26.3 & 23.8 & \\
\hline
\end{tabular}

Adapted from Pereira et al. (2000);

${ }^{\mathrm{a}, \mathrm{b}}$ in the same column differ within the breeding system $(\mathrm{P}<.05)$ by $\mathrm{t}$ teste;

$\mathrm{A}, \mathrm{B}$ in the same column differ between breeding system $(\mathrm{P}<.05)$ by $\mathrm{t}$ teste. 
The effects of heterosis and genetic group on the body growth traits were evaluated from the measurements and the animal weights. The heterosis of each trait was calculated by dividing the average measurements of the crossbred animals within each crossbreed generation by the average of the purebred, with this result subtracted from 1 and multiplied by 100 . The retained heterosis was also calculated, with the average of all crossbreeds divided by the average of the purebreds; the result was then subtracted from 1 and multiplied by 100 .

The data were analyzed by analysis of variance, and means were compared using the $t$-test, utilizing the following mathematical model:

$$
\mathrm{Y}_{\mathrm{ijkl}}=\mu+\mathrm{P}_{\mathrm{i}}+\mathrm{P} \times \mathrm{MS}_{\mathrm{ij}}+\mathrm{P} \times \mathrm{GG}(\mathrm{MS})_{\mathrm{ijk}}+\mathrm{IV}_{1}+\mathrm{E}_{\mathrm{ijk} \mathrm{k}}
$$

where: $\mathrm{Y}_{\mathrm{ijkl}}$ are the dependent variables (body measurements); $\mu$ is the average of all observations in the referred trait; and $\mathrm{P}_{\mathrm{i}}$ is the effect of the $i$-th age of observation of the measurements, which are 1 ( 8 months of age), 2 (12 months of age), 3 (18 months of age), and 4 (24 months of age). $\mathrm{P} \times \mathrm{MS}_{\mathrm{ij}}$ is the effect of the $i$-th period $\times j$-th mating system interaction that are an effect of the $j$-th mating system, with 1 (pure), 2 (crossbreed from G1), and 3 (crossbreed from G2). $\mathrm{P} \times \mathrm{GG}(\mathrm{MS})_{\mathrm{ikj}}$ is the effect of the $i$-th $\mathrm{P} \times$ $k$-th genetic group interaction within the $j$-th mating system, where GG corresponds to the effect of the genetic group of index $\mathrm{k}$, in which 1 refers to the Charolais and 2 to the Nellore breed, within $\mathrm{MS}_{\mathrm{j}}, 1$ corresponds to genetic group $1 / 2 \mathrm{C} 1 / 2 \mathrm{~N}$ and 2 to group 1/2 N 1/2 C within $\mathrm{MS}_{\mathrm{j}} 2$; 1 corresponds to animals $3 / 4 \mathrm{C} 1 / 4 \mathrm{~N}$ and 2 to animals $3 / 4 \mathrm{~N} 1 / 4 \mathrm{C}$. $\mathrm{IV}_{1}$ is the co-variable age of the mother of the male of index 1; and $\mathrm{E}_{\mathrm{ijkl}}$ is the random residual effect.

\section{Results and Discussion}

Considering the purebred animals, the Nellore were superior $(\mathrm{P}<.05)$ to the Charolais in rump height in all ages (Table 2). The difference in rump height was $4.4 ; 3.3 ; 7.6$ and $6.2 \%$, respectively, at $8,12,18$, and 24 months of age, in favor of the Nellore. The increase in the rump height from 8 to 24 months was $22.1 \mathrm{~cm}$ in Charolais and 25.3 $\mathrm{cm}$ in Nellore without statistical difference. The greater rump height of Nellore animals is a result of the natural selection process, because the breed originated in India had to adapt to the high temperatures, in which the larger distance between the body and the soil surface results in a lower body temperature on hotter days. Moreover, it should be considered that shrub species were originally present in their grazing environment, and taller animals had an advantage in that they moved more easily and adapt to this type of environment, which prevented injuries and promoted a better productive performance, but which caused them to become late maturing (FOGAGNOLI et al., 2010).

These factors, combined with high genetic variability and associated with heritability values ranging from 0.30 to 0.58 (CYRILLO et al., 2001), fixed the elevated height character in the Nellore breed. The increase in the height of zebu animals accompanies a slimmer body frame, as reported in other studies (PEROBELLI et al., 1995). The choice or selection of taller animals within a certain breed or genetic group may lead to an increase in body size (CAMPOS et al., 2015) and a reduction in early maturing and muscularity in long yearlings (KOURY FILHO et al., 2009; PEREIRA et al., 2010).

The G1 crossbred animals were similar $(\mathrm{P}>.05)$ to the purebred animals with respect to rump height averages from 8 to 12 months of age, and higher $(\mathrm{P}<.05)$ from 18 to 24 month, whereas the G2 crossbreds were taller than the purebred averages $(\mathrm{P}<.05)$ for all age groups (Table 2). The rump height of the G1 generation was intermediate between the purebred averages and $\mathrm{G} 2$, and did not differ $(\mathrm{P}>.05)$ from $\mathrm{G} 2$ in all age groups. The $\mathrm{G} 1$ heterosis for rump height was significant only at 18 and 24 months, while for the G2 it was significant in all age groups. Although 
there was higher individual heterozygosis of G1 animals, the heterosis was not significant at 8 and 12 month of age, and even though the G2 animals had lower individual heterozygosis, they displayed significant heterosis at all ages because they benefited from the maternal heterosis of their F1 dams. Cerdótes et al. (2004) reported that $\mathrm{F} 1$ cows produced more milk than purebreds, resulting in higher weight gain of their calves, and according to Rezende et al. (2011), the greater rump height of the animals could be explained by higher energy intake.

Table 2. Means, standard-errors and heterosis of rump height (cm) of males at different phases of development, according to genetic group.

\begin{tabular}{|c|c|c|c|c|c|}
\hline \multirow{2}{*}{$\begin{array}{c}\text { Genetic } \\
\text { Composition }\end{array}$} & \multicolumn{4}{|c|}{ Animals age, months } & \multirow{2}{*}{ Increase } \\
\hline & 8 & 12 & 18 & 24 & \\
\hline Charolais (C) & $103.5 \pm 1.3^{\mathrm{b}}$ & $111.6 \pm 1.3^{b}$ & $117.5 \pm 1.3^{\mathrm{b}}$ & $125.6 \pm 1.3^{\mathrm{b}}$ & $22.1 \pm 1.2^{\mathrm{a}}$ \\
\hline Nellore (N) & $108.1 \pm 1.5^{\mathrm{a}}$ & $115.3 \pm 1.5^{\mathrm{a}}$ & $126.5 \pm 1.5^{\mathrm{a}}$ & $133.4 \pm 1.6^{\mathrm{a}}$ & $25.3 \pm 1.4^{\mathrm{a}}$ \\
\hline Straigthbreeds means & $105.8 \pm 1.0^{\mathrm{B}}$ & $113.5 \pm 1.0^{\mathrm{B}}$ & $122.0 \pm 1.0^{\mathrm{B}}$ & $129.5 \pm 1.0^{\mathrm{B}}$ & $23.7 \pm 0.9^{\mathrm{B}}$ \\
\hline $1 / 2 \mathrm{C} 1 / 2 \mathrm{~N}$ & $108.0 \pm 2.0^{\mathrm{a}}$ & $115.6 \pm 2.0^{\mathrm{a}}$ & $126.8 \pm 2.0^{\mathrm{a}}$ & $134.1 \pm 2.0^{\mathrm{a}}$ & $26.1 \pm 1.8^{\mathrm{a}}$ \\
\hline $1 / 2 \mathrm{~N} 1 / 2 \mathrm{C}$ & $108.6 \pm 1.7^{\mathrm{a}}$ & $118.0 \pm 1.7^{\mathrm{a}}$ & $128.1 \pm 1.7^{\mathrm{a}}$ & $136.7 \pm 1.7^{\mathrm{a}}$ & $28.1 \pm 1.5^{\mathrm{a}}$ \\
\hline G1 means & $108.3 \pm 1.4^{\mathrm{AB}}$ & $116.8 \pm 1.4^{\mathrm{AB}}$ & $127.5 \pm 1.4^{\mathrm{A}}$ & $135.4 \pm 1.4^{\mathrm{A}}$ & $27.1 \pm 1.2^{\mathrm{A}}$ \\
\hline $3 / 4 \mathrm{C}^{1 / 4} \mathrm{~N}$ & $110.0 \pm 1.5^{\mathrm{a}}$ & $117.4 \pm 1.5^{\mathrm{a}}$ & $124.4 \pm 1.5^{\mathrm{b}}$ & $132.1 \pm 1.5^{\mathrm{b}}$ & $22.1 \pm 1.3^{\mathrm{b}}$ \\
\hline $3 / 4 \mathrm{~N}^{1 / 4} \mathrm{C}$ & $111.1 \pm 2.0^{\mathrm{a}}$ & $119.2 \pm 1.9^{\mathrm{a}}$ & $129.8 \pm 2.0^{\mathrm{a}}$ & $137.9 \pm 1.9^{\mathrm{a}}$ & $26.8 \pm 1.8^{\mathrm{a}}$ \\
\hline G2 means & $110.6 \pm 1.3^{\mathrm{A}}$ & $118.3 \pm 1.3^{\mathrm{A}}$ & $127.1 \pm 1.3^{\mathrm{A}}$ & $135.0 \pm 1.3^{\mathrm{A}}$ & $24.4 \pm 1.1^{\mathrm{AB}}$ \\
\hline \multicolumn{6}{|l|}{ Heterosis, \% } \\
\hline G1 & 2.36 & 2.91 & $4.51^{*}$ & $4.56^{*}$ & \\
\hline G2 & $4.54 *$ & $4.29 *$ & $4.18^{*}$ & $4.25^{*}$ & \\
\hline Retained heterosis & 3.45 & 3.60 & 4.35 & 4.41 & \\
\hline \multicolumn{6}{|c|}{ Crossbreds difference vs } \\
\hline Charolais $(\%)$ & 0.91 & 5.33 & 8.35 & 4.40 & \\
\hline Nellore (\%) & 1.25 & 1.95 & 0.63 & 1.35 & \\
\hline
\end{tabular}

${ }^{a, b}$ in the same column differ within the breeding system $(\mathrm{P}<.05)$ by $\mathrm{t}$ teste;

$\mathrm{A}, \mathrm{B}$ in the same column differ between breeding system $(\mathrm{P}<.05)$ by $\mathrm{t}$ teste.

* Statistical difference $(\mathrm{P}<.05)$ when comparing crossbreds vs straigthbreeds.

The height of an animal is of fundamental importance because of its positive association with metabolic body size and consequently with its physical requirements (BIF, 2014). The selection of animals based exclusively on body weight might lead to larger-sized animals which reared in systems with feed restrictions may become late maturing and consequently less efficient (PEREIRA et al., 2010), as there are reports of negative genetic correlations between rump height and carcass fat thickness (YOKOO et al., 2010).
Early maturing might not be explicit in all situations, since in the present study involving different biotypes, the Charolais, because of their greater adult weight, were later maturing compared with the Nellore. The adult weight of animals can be measured from five years on in large-sized breeds (BOLIGON et al., 2008), or from four years on in medium-sized breeds (ROSA et al., 2000), and weight might be positively correlated with body condition scores of Nellore cows (MERCADANTE et al., 2006). However, in the larger-sized breed 
Brahman, also zebu, studies have shown that the body condition was significantly higher than for smaller sized animals (LIMA et al., 2004).

Nevertheless, regarding the precocity for age at puberty, body weight is a decisive factor in its manifestation. Studying the growth of heifers from weaning to first heat from the same genetic groups, Restle et al. (1999b) observed that the Charolais heifers were heavier and younger at puberty as compared with the Nellore heifers, with heterosis being significant for both traits. Positive genetic correlations between growth traits and rump height are high, but the reproductive efficiency is not greatly affected by the rump height (PEREIRA et al., 2010).

In the comparison of rump height measurements between crossbreds and purebreds, a positive difference was obtained in favor of the crossbreds, with the values observed for the Nellore being very similar to them, whereas the values observed for the Charolais animals were lower, with the difference expressed in percentage showing a quadratic behavior. This assertion is based on the peaks observed in the intermediate ages and a deceleration in the growth of the crossbred animals as they aged, which followed the weight development of the animals, with the crossbred losing their superiority compared to the Charolais animals (MENEZES et al., 2008). Moreover, the rump height of the $3 / 4 \mathrm{C} 1 / 4 \mathrm{~N}$ crossbreds was similar to the $3 / 4 \mathrm{~N} 1 / 4 \mathrm{C}$ crossbreds at 8 and 12 months of age, however, after that the $3 / 4 \mathrm{~N} 1 / 4^{\mathrm{C}}$ crossbreds became taller.

Charolais males displayed higher measurements in the ischial opening compared to the Nellore males in all ages (Table 3) ranging from $6.41 \%$ at 12 months to $26.14 \%$ at 8 months of age. This difference is a result of the intense selection of the Charolais breed for muscle development and weight gain, which are determinants of greater development, body size, and consequently adult weight. Higher muscle expression values in adult Charolais cull cows compared to Nellore were reported by Restle et al. (2002), who evaluated subjectively the carcass conformation. These results were objectively proved through the higher carcass Longissimus dorsi muscle area, cushion thickness, and forearm perimeter. These measurements are positively correlated with muscle production in the carcass, demonstrating the greater meat potential of Charolais cull cows compared with the Nellore cows in South Brazil (RESTLE et al., 2002).

Considering the crossbreds, the ischial opening (Table 3 ) and rump width (Table 4) behaved similarly as the males grew, without differences between the genetic groups within the G1 and G2 generations, except for rump width at 8 months of age in the $\mathrm{G} 2$ animals, when $3 / 4 \mathrm{C}_{1} \quad 1 / 4 \mathrm{~N}$ displayed higher averages than the $3 / 4 \mathrm{~N} 1 / 4 \mathrm{C}$ (34.2 versus $29.6 \mathrm{~cm}$ ). This difference most likely occurred because of the greater maternal ability of the cows (CERDÓTES et al., 2004; AZAMBUJA et al., 2008) during the development stage where animals depend almost exclusively on nutrients originating from maternal milk (VAZ et al., 2010) and because of the higher percentage of Charolais genetic composition, since this breed is selected for heavier weight and, consequently, has a larger body size. Additionally, these animals are less susceptible to weaning stress compared with purebred animals or animals with a predominance of the Nellore (RESTLE et al., 1999a). 
Table 3. Means, standard-errors and heterosis of ischial opening $(\mathrm{cm})$ of males at different phases of development, according to genetic group.

\begin{tabular}{|c|c|c|c|c|c|}
\hline \multirow{2}{*}{$\begin{array}{c}\text { Genetic } \\
\text { composition }\end{array}$} & \multicolumn{4}{|c|}{ Animals age, months } & \multirow{2}{*}{ Increase } \\
\hline & 8 & 12 & 18 & 24 & \\
\hline Charolais (C) & $19.3 \pm 0.54^{\mathrm{a}}$ & $24.9 \pm 0.54^{\mathrm{a}}$ & $27.8 \pm 0.54^{\mathrm{a}}$ & $30.8 \pm 0.54^{\mathrm{a}}$ & $11.5 \pm 0.7^{\mathrm{a}}$ \\
\hline Nellore (N) & $15.3 \pm 0.59^{\mathrm{b}}$ & $23.4 \pm 0.62^{\mathrm{b}}$ & $25.1 \pm 0.62^{b}$ & $27.0 \pm 0.64^{\mathrm{b}}$ & $11.7 \pm 0.6^{\mathrm{a}}$ \\
\hline Straighbreds means & $17.3 \pm 0.40^{\mathrm{A}}$ & $24.2 \pm 0.40^{\mathrm{B}}$ & $26.4 \pm 0.41^{\mathrm{B}}$ & $28.9 \pm 0.42^{\mathrm{B}}$ & $11.6 \pm 0.4^{\mathrm{A}}$ \\
\hline $1 / 2 \mathrm{C} 1 / 2 \mathrm{~N}$ & $18.0 \pm 0.83^{\mathrm{a}}$ & $24.9 \pm 0.83^{\mathrm{a}}$ & $27.6 \pm 0.83^{\mathrm{a}}$ & $30.4 \pm 0.83^{\mathrm{a}}$ & $12.4 \pm 0.9^{\mathrm{a}}$ \\
\hline $1 / 2 \mathrm{~N}^{1 / 2} \mathrm{C}$ & $18.6 \pm 0.69^{\mathrm{a}}$ & $26.6 \pm 0.69^{\mathrm{a}}$ & $28.7 \pm 0.69^{\mathrm{a}}$ & $31.2 \pm 0.69^{\mathrm{a}}$ & $12.6 \pm 0.7^{\mathrm{a}}$ \\
\hline G1 means & $18.3 \pm 0.55^{\mathrm{A}}$ & $25.8 \pm 0.55^{\mathrm{A}}$ & $28.2 \pm 0.55^{\mathrm{A}}$ & $30.8 \pm 0.55^{\mathrm{A}}$ & $12.5 \pm 0.6^{\mathrm{A}}$ \\
\hline $3 / 4 \mathrm{C} 1 / 4 \mathrm{~N}$ & $19.8 \pm 0.60^{\mathrm{a}}$ & $24.5 \pm 0.60^{\mathrm{a}}$ & $25.5 \pm 0.60^{\mathrm{a}}$ & $31.0 \pm 0.62^{\mathrm{a}}$ & $11.2 \pm 0.6^{\mathrm{a}}$ \\
\hline $3 / 4 \mathrm{~N}^{1 / 4} \mathrm{C}$ & $18.2 \pm 0.83^{\mathrm{a}}$ & $25.5 \pm 0.79^{\mathrm{a}}$ & $24.3 \pm 0.84^{\mathrm{a}}$ & $30.7 \pm 0.79^{\mathrm{a}}$ & $12.5 \pm 0.9^{\mathrm{a}}$ \\
\hline G2 means & $19.0 \pm 0.53^{\mathrm{A}}$ & $25.0 \pm 0.51^{\mathrm{AB}}$ & $28.0 \pm 0.53^{\mathrm{A}}$ & $30.9 \pm 0.51^{\mathrm{A}}$ & $11.9 \pm 0.5^{\mathrm{A}}$ \\
\hline \multicolumn{6}{|l|}{ Heterosis, \% } \\
\hline G1 & 5.78 & $6.61 *$ & $6.81 *$ & $6.57 *$ & \\
\hline G2 & 9.83 & 3.30 & $6.06^{*}$ & $6.92 *$ & \\
\hline Retained heterosis & 7.81 & 4.96 & 6.43 & 6.75 & \\
\hline \multicolumn{6}{|c|}{ Crossbreds difference vs } \\
\hline Charolais $(\%)$ & -3.37 & 2.00 & 1.07 & 0.16 & \\
\hline Nellore (\%) & 21.89 & 8.55 & 11.95 & 14.26 & \\
\hline
\end{tabular}

${ }^{a, b}$ in the same column differ within the breeding system $(\mathrm{P}<.05)$ by $\mathrm{t}$ teste;

$\mathrm{A}, \mathrm{B}$ in the same column differ between breeding system $(\mathrm{P}<.05)$ by $\mathrm{t}$ teste.

* Statistical difference $(\mathrm{P}<.05)$ when comparing crossbred vs straigthbred.

Table 4. Means, standard-errors and heterosis of rump width $(\mathrm{cm})$ of males at different phases of development, according to genetic group.

\begin{tabular}{|c|c|c|c|c|c|}
\hline \multirow{2}{*}{$\begin{array}{c}\text { Genetic } \\
\text { composition }\end{array}$} & \multicolumn{4}{|c|}{ Animals age, months } & \multirow{2}{*}{ Increase } \\
\hline & 8 & 12 & 18 & 24 & \\
\hline Charolais (C) & $32.9 \pm 0.81^{\mathrm{a}}$ & $38.5 \pm 0.82^{\mathrm{a}}$ & $41.9 \pm 0.82^{\mathrm{a}}$ & $45.4 \pm 0.82^{\mathrm{a}}$ & $12.5 \pm 1.0^{\mathrm{a}}$ \\
\hline Nellore (N) & $29.2 \pm 0.89^{\mathrm{b}}$ & $36.2 \pm 0.92^{\mathrm{a}}$ & $39.6 \pm 0.93^{\mathrm{a}}$ & $43.8 \pm 0.96^{\mathrm{a}}$ & $14.6 \pm 1.2^{\mathrm{a}}$ \\
\hline Straigthbreds means & $31.1 \pm 0.61^{\mathrm{A}}$ & $37.4 \pm 0.62^{\mathrm{B}}$ & $40.8 \pm 0.62^{\mathrm{B}}$ & $44.6 \pm 0.63^{\mathrm{B}}$ & $13.5 \pm 0.8^{\mathrm{A}}$ \\
\hline $1 / 2 \mathrm{C} 1 / 2 \mathrm{~N}$ & $31.5 \pm 1.25^{\mathrm{a}}$ & $38.9 \pm 1.25^{\mathrm{a}}$ & $43.3 \pm 1.25^{\mathrm{a}}$ & $47.9 \pm 1.25^{\mathrm{a}}$ & $16.4 \pm 1.5^{\mathrm{a}}$ \\
\hline $1 / 2 \mathrm{~N}^{1 / 2} \mathrm{C}$ & $34.2 \pm 1.03^{\mathrm{a}}$ & $40.6 \pm 1.03^{\mathrm{a}}$ & $44.6 \pm 1.04^{\mathrm{a}}$ & $48.1 \pm 1.03^{\mathrm{a}}$ & $13.9 \pm 1.2^{\mathrm{a}}$ \\
\hline G1 means & $32.9 \pm 0.84^{\mathrm{A}}$ & $39.8 \pm 0.84^{\mathrm{A}}$ & $41.0 \pm 0.84^{\mathrm{A}}$ & $48.0 \pm 0.84^{\mathrm{A}}$ & $15.1 \pm 0.9^{\mathrm{A}}$ \\
\hline $3 / 4$ C $1 / 4 \mathrm{~N}$ & $34.2 \pm 0.90^{\mathrm{a}}$ & $37.6 \pm 0.90^{\mathrm{a}}$ & $41.9 \pm 0.91^{\mathrm{a}}$ & $46.5 \pm 0.93^{\mathrm{a}}$ & $12.3 \pm 1.1^{\mathrm{a}}$ \\
\hline $3 / 4 \mathrm{~N}^{1 / 4} \mathrm{C}$ & $29.6 \pm 1.25^{\mathrm{b}}$ & $39.4 \pm 1.18^{\mathrm{a}}$ & $42.6 \pm 1.26^{\mathrm{a}}$ & $46.1 \pm 1.18^{\mathrm{a}}$ & $16.5 \pm 1.5^{\mathrm{a}}$ \\
\hline G2 means & $31.9 \pm 0.80^{\mathrm{A}}$ & $38.5 \pm 0.77^{\mathrm{AB}}$ & $42.3 \pm 0.80^{\mathrm{A}}$ & $46.3 \pm 0.78^{\mathrm{AB}}$ & $14.4 \pm 0.9^{\mathrm{A}}$ \\
\hline \multicolumn{6}{|l|}{ Heterosis, \% } \\
\hline G1 & 5.79 & $6.42 *$ & 0.4 & $7.62 *$ & \\
\hline G2 & 2.57 & 2.94 & $3.67 *$ & 3.81 & \\
\hline Retained heterosis & 4.18 & 4.68 & 2.08 & 5.72 & \\
\hline \multicolumn{6}{|c|}{ Crossbreds difference vs } \\
\hline Charolais $(\%)$ & -1.52 & 4.68 & 0.5 & 3.85 & \\
\hline Nellore (\%) & 10.96 & 8.15 & 5.18 & 7.64 & \\
\hline
\end{tabular}

a,b in the same column differ within the breeding system $(\mathrm{P}<.05)$ by $\mathrm{t}$ teste;

$\mathrm{A}, \mathrm{B}$ in the same column differ between breeding system $(\mathrm{P}<.05)$ by $\mathrm{t}$ teste.

* Statistical difference $(\mathrm{P}<.05)$ when comparing crossbred vs straigthbreds. 
The ischial opening and rump width in males are essential parameters in the selection of animals, because larger values are related to a larger muscle deposition area (DI MARCO et al., 2007), and these are also the regions of more valuable cuts in the bovine carcass (PASCOAL et al., 2010). Animal breeding programs that study the phenotypic evolution of animals in relation to productivity seek large and deep hindquarters, aiming for a higher percentage of the more valuable meat cuts in the carcass, thereby adding value to the production process (MOURÃO et al., 2010). Although they were not evaluated in the present study, these measurements are also important in females as they are related to ease at calving (PILAU; LOBATO, 2009) and larger udder insertion area in the future dams of the herd (LAGROTTA et al., 2010).

Heterosis was manifested positively in the different phases of evaluation, in both ischial opening (Table 3) and rump width (Table 4), although not significantly different in all the age periods evaluated. In his study, Restle et al. (2002) observed that in addition to the superiority of the Charolais cows in relation to the Nellore cows, crossbreeding between these breeds resulted in satisfactory levels of heterosis for important carcass related traits. Combining in the F1 animals with greater cold carcass weight and carcass conformation (that are important characteristics of the Charolais breed), and carcass yield and subcutaneous fat thickness (that are important characteristics of the Nellore breed), resulted in animals that produced carcasses with high weight, good conformation, and a high degree of subcutaneous fat (RESTLE et al., 2002).

Observing the contrast analysis (Tables 3 and 4) there was similarity between the measurements of crossbreds and Charolais. At 8 months of age, there was a superiority of rump width of the Charolais in relation to the Nellore, demonstrating the early bone development to support the larger adult body weight, typical of the Continental breeds.
The selection of Continental breeds in Europe sought meat production and labor, resulting in larger animals with more muscle mass than other European breeds, especially the British, which were selected for production of animals with good carcass finishing and marbled meat (CUNDIFF; GREGORY, 1980). A similar relationship could be made for the Nellore breed, because the zebu were naturally selected for rusticity in response to hot climates, resulting in animals with slimmer frames, that are lighter and with less muscle and bone tissue mass, but with better carcass fat finishing (RESTLE et al., 2002).

With the advancement of age, the superiority in growth of crossbreds because of heterozygosity, began to manifest in relation to both the Charolais and Nellore breeds, being more evident in relation to the latter, which did not suffered in its formation, selection for body development (KRATZ et al., 2001).

At 8 months of age, the ischial opening and rump width in the Nellore was, respectively, 21.89 (Table 3 ) and $10.96 \%$ (Table 4) lower than the crossbreds, demonstrating that the maternal effect on animals growth occurs before the weaning age and that the genotypes respond differently to weaning stress. Subsequently, the Nellore animals reduced the difference compared to the crossbreds, although with values still inferior in body development.

The differences between crossbreds and purebreds, expressed by the heterosis values, show that crossbreeding is an alternative to improve animal performance (RESTLE et al., 1999a; PEREIRA et al., 2000), taking advantage of the effect of the direct and maternal heterosis resulting from the crossbreeding (GREGORY et al., 1991). This is important primarily for better animal performance when there are nutritional limitations resulting from climatic variations that interfere with the production and quality of natural pastures, particularly when these are the basic feed for the cattle (VAZ et al., 2012). 
The thoracic perimeter of the Charolais was significantly larger than that in the Nellore at 8, 12 and 18 months of age (Table 5), without significant difference at 24 months. The thoracic perimeter difference between the two breeds was similar at 8 and 12 months, declined at 18 months, and disappeared at 24 months close to slaughter, demonstrating a deceleration in growth of the Charolais as compared to that of the Nellore or because the deposition of subcutaneous fat was higher in the rib region in the Nellore animals. The greater deposition of fat in the Nellore might have led to a greater accumulation of fat in the thoracic region, which was a decisive factor in the nonexistence of differences near the slaughter.
Comparing the same genetic groups, Restle et al. (2000) verified an additive genetic effect of the Charolais breed reflected in lower fat deposition in the carcass compared with the Nellore breed.

The thoracic perimeter did not differ $(\mathrm{P}>.05)$ within the crossbred generations between the genetic groups, irrespective of the evaluated ages. The only exception was at 8 months of age in G2, in which the highest mean was observed in the animals with greater Charolais genetic composition, because of the selection of the breed for greater muscle development, weight gain, and adult weight, and because of the lower stress of the animals at weaning.

Table 5. Means, standard-errors and heterosis of thoracic perimeter $(\mathrm{cm})$ of males at different phases of development, according to genetic group.

\begin{tabular}{|c|c|c|c|c|c|}
\hline \multirow{2}{*}{$\begin{array}{c}\text { Genetic } \\
\text { Composition }\end{array}$} & \multicolumn{4}{|c|}{ Animals age, months } & \multirow{2}{*}{ Increase } \\
\hline & 8 & 12 & 18 & 24 & \\
\hline Charolais (C) & $124.1 \pm 2.0^{\mathrm{a}}$ & $144.9 \pm 2.0^{\mathrm{a}}$ & $156.1 \pm 2.0^{\mathrm{a}}$ & $169.8 \pm 2.0^{\mathrm{a}}$ & $45.7 \pm 1.7^{\mathrm{b}}$ \\
\hline Nellore (N) & $116.8 \pm 2.2^{\mathrm{b}}$ & $136.8 \pm 2.2^{\mathrm{b}}$ & $150.4 \pm 2.2^{\mathrm{b}}$ & $169.2 \pm 2.3^{\mathrm{a}}$ & $52.4 \pm 2.0^{\mathrm{a}}$ \\
\hline Straigthbreds means & $120.0 \pm 1.5^{\mathrm{A}}$ & $140.9 \pm 1.5^{\mathrm{B}}$ & $153.3 \pm 1.5^{\text {В }}$ & $169.5 \pm 1.5^{\mathrm{B}}$ & $49.5 \pm 1.3^{\mathrm{B}}$ \\
\hline $1 / 2 \mathrm{C} 1 / 2 \mathrm{~N}$ & $120.6 \pm 3.0^{\mathrm{a}}$ & $146.7 \pm 3.0^{\mathrm{a}}$ & $160.1 \pm 3.0^{\mathrm{a}}$ & $180.7 \pm 3.0^{\mathrm{a}}$ & $60.1 \pm 2.6^{\mathrm{a}}$ \\
\hline $1 / 2 \mathrm{~N}^{1 / 2} \mathrm{C}$ & $125.2 \pm 2.5^{\mathrm{a}}$ & $147.6 \pm 2.5^{\mathrm{a}}$ & $160.3 \pm 2.5^{\mathrm{a}}$ & $181.7 \pm 2.5^{\mathrm{a}}$ & $55.5 \pm 2.1^{\mathrm{a}}$ \\
\hline G1 means & $122.9 \pm 2.0^{\mathrm{A}}$ & $147.2 \pm 2.0^{\mathrm{A}}$ & $160.2 \pm 2.0^{\mathrm{A}}$ & $180.7 \pm 2.0^{\mathrm{A}}$ & $57.8 \pm 1.7^{\mathrm{A}}$ \\
\hline $3 / 4 \mathrm{C} 1 / 4 \mathrm{~N}$ & $127.2 \pm 2.2^{\mathrm{a}}$ & $146.0 \pm 2.2^{\mathrm{a}}$ & $158.1 \pm 2.2^{\mathrm{a}}$ & $176.1 \pm 2.3^{\mathrm{a}}$ & $49.1 \pm 1.9^{b}$ \\
\hline $3 / 4 \mathrm{~N}^{1 / 4} \mathrm{C}$ & $120.9 \pm 3.0^{\mathrm{b}}$ & $143.2 \pm 2.9^{\mathrm{a}}$ & $160.4 \pm 3.0^{\mathrm{a}}$ & $178.9 \pm 2.9^{\mathrm{a}}$ & $58.0 \pm 2.6^{\mathrm{a}}$ \\
\hline G2 means & $124.5 \pm 1.9^{\mathrm{A}}$ & $144.6 \pm 1.9^{\mathrm{AB}}$ & $159.3 \pm 1.9^{\mathrm{A}}$ & $177.5 \pm 1.9^{\mathrm{A}}$ & $53.0 \pm 1.6^{\mathrm{A}}$ \\
\hline \multicolumn{6}{|l|}{ Heterosis, \% } \\
\hline G1 & 2.42 & $4.47^{*}$ & $4.50 *$ & $6.61 *$ & \\
\hline G2 & 3.75 & 2.63 & $3.91 *$ & $4.72 *$ & \\
\hline Retained heterosis & 3.08 & 3.55 & 4.21 & 5.66 & \\
\hline \multicolumn{6}{|c|}{ Crossbreds difference vs } \\
\hline Charolais (\%) & -0.33 & 0.69 & 2.34 & 5.48 & \\
\hline Nellore (\%) & 5.91 & 3.55 & 6.22 & 5.85 & \\
\hline
\end{tabular}

${ }_{a, b}$ in the same column differ within the breeding system $(\mathrm{P}<.05)$ by $\mathrm{t}$ teste;

$\mathrm{A}, \mathrm{B}$ in the same column differ between breeding system $(\mathrm{P}<.05)$ by $\mathrm{t}$ teste.

* Statistical difference $(\mathrm{P}<.05)$ when comparing crossbred vs straigthbreds. 
The thoracic perimeter is the body measurement with the lowest variation and is the most precise in determining growth (PACHECO et al., 2008). In the comparison between the crossbreds and purebreds, a more marked superiority was obtained in the former compared to the Nellore, demonstrating the smaller body size of the Nellore breed and the non-selection of this breed for body size, but rather for adaptation to the tropical environment. This difference was not as expressive when crossbreds were compared with the Charolais.

The evaluated measurements increased in all genetic groups, following the body weight gain of the animals (Table 6). In the averages of the crossbred G1 and G2 generations, no significant differences occurred in relative development between the body weights and measurements of the animals. In the $3 / 4$ $\mathrm{N} 1 / 4 \mathrm{C}$ animals of $\mathrm{G} 2$ generation, the weight gain for every centimeter of increase in thoracic perimeter was lower $(\mathrm{P}<.05)$ than for the other crossbreds. The results demonstrate that the increase in weight is highly correlated with an increase in body size. A greater development of the thoracic perimeter is a consequence of the muscle and fat depositions having different growth curves than that of the skeleton, which stops developing when the animal reaches maturity (ROCHA et al., 2003). However, evaluating the morphology of Nellore cattle and crosses with Limousin cattle, Mourão et al. (2010) did not find differences in morphometric measurements such as height, rump length, and thoracic perimeter, but these authors worked with similar slaughter weights, demonstrating that the morphometric measurements are related to the development of the animals.

Between the purebred animals, differences occurred in growth in units of weight per $\mathrm{cm}$, with the Charolais animals having greater weight gain per cm of rump height and rump width, and the Nellore animals having greater weight gain per $\mathrm{cm}$ of thoracic perimeter. The greater growth in rump width in the Charolais animals is partly owing to the selection of the breed for muscle development and growth. In the present study, early-weaned Charolais animals did not experience full development, partially because of dietary deficiencies and their higher maintenance requirements since they were heavier than the Nellore animals, whose energy requirements were supplied by their mother's milk (RESTLE et al., 1995). European breeds and their inclusion in crosses with zebu breeds normally increase the weight of the animals, and this has a direct relationship on the resulting animal size and rump height (PEROTTO et al., 2000).

The measurements of ischial opening responded similarly to rump height, with greater growth observed in the Charolais than in the Nellore in units of weight per $\mathrm{cm}$. These results are the effects of the intense selection in the Charolais breed for growth and muscle development to which it was subjected to during its formation; as a consequence, it requires a larger bone structure. Despite their larger muscle deposition, Charolais animals do not have a greater proportion of bones, but rather a larger rump width, responsible for the results of greater muscle deposition and better conformation and lower proportion of bones in the carcass (RESTLE et al., 2001). 
Table 6. Means, standard-errors and heterosis of relative body weight gains relatively to rump height, ischial opening, rump width and thoracic perimeter $(\mathrm{cm})$ from 8 to 24 months of age of males, according to the genetic group.

\begin{tabular}{lcccc}
\hline \multirow{2}{*}{$\begin{array}{c}\text { Genetic } \\
\text { Composition }\end{array}$} & \multicolumn{4}{c}{ Relative gains (weight gain /measurement gain) } \\
\cline { 2 - 5 } Chump height & Ischial opening & Rump width & Thoracic perimeter \\
\hline Nellore (N) & $11.7 \pm 0.9^{\mathrm{a}}$ & $22.0 \pm 1.6^{\mathrm{a}}$ & $22.0 \pm 1.5^{\mathrm{a}}$ & $4.48 \pm 0.15^{\mathrm{b}}$ \\
Straightbreds mean & $11.3 \pm 1.1^{\mathrm{b}}$ & $21.0 \pm 1.9^{\mathrm{a}}$ & $17.1 \pm 1.7^{\mathrm{b}}$ & $5.46 \pm 0.18^{\mathrm{a}}$ \\
$1 / 2 \mathrm{C} 1 / 2 \mathrm{~N}$ & $11.5 \pm 0.70^{\mathrm{A}}$ & $21.5 \pm 1.2^{\mathrm{B}}$ & $19.5 \pm 1.2^{\mathrm{A}}$ & $5.00 \pm 0.12^{\mathrm{A}}$ \\
$1 / 2 \mathrm{~N} 1 / 2 \mathrm{C}$ & $12.3 \pm 1.4^{\mathrm{a}}$ & $28.3 \pm 2.4^{\mathrm{a}}$ & $19.4 \pm 2.2^{\mathrm{a}}$ & $5.25 \pm 0.23^{\mathrm{a}}$ \\
Média da G1 & $10.8 \pm 1.1^{\mathrm{a}}$ & $24.4 \pm 2.0^{\mathrm{a}}$ & $23.2 \pm 1.8^{\mathrm{a}}$ & $5.34 \pm 0.29^{\mathrm{a}}$ \\
$3 / 4 \mathrm{C} 1 / 4 \mathrm{~N}$ & $11.6 \pm 0.88^{\mathrm{A}}$ & $26.3 \pm 1.6^{\mathrm{A}}$ & $21.3 \pm 1.4^{\mathrm{A}}$ & $5.30 \pm 0.15^{\mathrm{A}}$ \\
$3 / 4 \mathrm{~N} 1 / 4 \mathrm{C}$ & $12.8 \pm 1.0^{\mathrm{a}}$ & $24.9 \pm 1.8^{\mathrm{a}}$ & $22.9 \pm 1.6^{\mathrm{a}}$ & $5.45 \pm 0.17^{\mathrm{a}}$ \\
Média da G2 & $10.2 \pm 1.4^{\mathrm{a}}$ & $21.5 \pm 2.4^{\mathrm{a}}$ & $19.4 \pm 2.2^{\mathrm{a}}$ & $4.78 \pm 0.23^{\mathrm{b}}$ \\
Heteroses, \% & $11.5 \pm 0.84^{\mathrm{A}}$ & $23.2 \pm 1.5^{\mathrm{A}}$ & $21.2 \pm 1.4^{\mathrm{A}}$ & $5.10 \pm 0.14^{\mathrm{A}}$ \\
G1 & & & & \\
G2 & 0.86 & $22.32^{*}$ & 9.23 & 6.00 \\
Retida & 0.00 & $7.91^{*}$ & 8.72 & 2.00 \\
Crossbreds Diferences vs. & 0.43 & 15.12 & 8.97 & 4.00 \\
Charolais (\%) & & & & \\
Nellore (\%) & -1.28 & 12.5 & -3.41 & 16.07 \\
\hline
\end{tabular}

${ }^{a, b}$ in the same column differ within the breeding system $(\mathrm{P}<.05)$ by $t$ teste;

$\mathrm{A}, \mathrm{B}$ in the same column differ between breeding system $(\mathrm{P}<.05)$ by $\mathrm{t}$ teste.

* Statistical difference $(\mathrm{P}<.05)$ when comparing crossbred vs straigthbreds.

No significant differences were found between the crossbred and purebred animals, except for the increase in ischial opening in units of weight per $\mathrm{cm}$ of growth where the crossbred animals, regardless of the generation, had higher measurements than the purebred animals, but they did not differ from each other. Despite the lack of significant differences, increases in heterosis were present in both generations for the relative growth in units of weight per increase in body measurements.

The correlations between body measurements, irrespective of the evaluation period, were significant and positive $(\mathrm{P}<.01)$, indicating that animal growth is uniform and harmonious among the variables related to development. When the morphometric measurements were correlated with the total weight gain of the animals from 8 to 24 months, positive and significant correlation
$(\mathrm{P}<.01 ; \mathrm{P}<.05)$ was observed, which demonstrates the association between animal growth and development. The thoracic circumference had the highest correlation with weight gain $(.70 ; \mathrm{P}<.01)$ of the morphometric measurements, indicating that it can be utilized for the prediction of animal weight when scales are not available, and it should be further studied to obtain more accurate facts (LÔBO et al., 2002).

Other measurements such as length and height might vary according to skeletal growth, and can also vary according to the deposition of fat that affects the points of reference of the measurements, with its growth ceasing when the animal reaches maturity (ROCHA et al., 2003), while the thoracic perimeter is the linear measurement of greatest precision in the determination of muscle growth. 


\section{Conclusions}

Crossbred males from rotational crossbreeding between the Charolais and Nellore breeds show higher morphometric values when compared with purebred animals, displaying significant heterosis.

Among the purebred animals, the bovines of Nellore breed are superior in rump height, whereas the Charolais have greater thoracic-circumference measures from 8 to 18 months, and higher ischial opening.

The body measurements showed high correlations with each other and with the body weight, so they are good indicators of weight development.

\section{References}

AZAMBUJA, P. S.; PILAU, A.; LOBATO, J. F. P. Suplementação alimentar de novilhas no pós-desmame: efeitos no crescimento e desempenho reprodutivo. Revista Brasileira de Zootecnia, Viçosa, MG, v. 37, n. 6, p. 1042-1049, 2008.

BEEF IMPROVEMENT FEDERATION - BIF. Guidelines, for uniform beef improvement programs. $9^{\text {th }}$ ed. Athens: Beef Improvement Federation and North Carolina State University, 2014. 182 p.

BOLIGON, A. A.; ALBUQUERQUE, L. G.; MERCADANTE, M. E. Z.; LOBÔ, R. B. Models for genetic evaluation of Nelore cattle mature body weight. Journal of Animal Science, Champaign, v. 86, n. 11, p. 2840-2844, 2008.

CAMPOS, R. V.; COBUCI, J. A.; KERN, E. L.; COSTA, C. N.; MCMANUS, C. M. Genetic parameters for linear type traits and milk, fat, and protein production in holstein cows in Brazil. Asian-Australasian Journal of Animal Sciences, Seoul, v. 28, n. 4, p. 476-484, 2015.

CERDÓTES, L.; RESTLE, J.; ALVES FILHO, D. C.; PACHECO, P. S.; MISSIO, R. L.; GARAGORRY, F. C. Desempenho de bezerros de corte filhos de vacas submetidas a diferentes manejos alimentares, desmamados aos 42 ou 63 dias de idade. Revista Brasileira de Zootecnia, Viçosa, MG, v. 33, n. 3, p. 597 609, 2004.

CYRILLO, J. N. S. G.; RAZOOK, A. G.; FIGUEIREDO, L. A.; BONILHA NETO, L. M.; MERCADANTE, M. E. Z.; TONHATI, H. Estimativas de tendências e parâmetros genéticos do peso padronizado aos 378 dias de idade, medidas corporais e perímetro escrotal de machos nelore de Sertãozinho, SP. Revista Brasileira de Zootecnia, Viçosa, MG, v. 30, n. 1, p. 56-65, 2001.

DI MARCO, O. N.; BARCELLOS, J. O. J.; COSTA, E. C. Crescimento de bovinos de corte. Porto Alegre: Gráfica da UFRGS, 2007. 278 p.

FOGAGNOLI, A. F. M.; SILVA, E. A. da; AMORIM, C. A.; FOGAGNOLI, S. W.; NIETO, L. M.; CALVIS, D. S. Morfometria, avaliações visuais (EPMURAS) e desempenho em animais da raça nelore. Caderno de PósGraduação, Uberlândia, v. 1, n. 1, p. 1-9, 2010.

GREGORY, K. E.; CUNDIFF, L. V. Crossbreeding in beef cattle: evaluation of systems. Journal of Animal Science, Champaign, v. 51, n. 5, p. 1224-1241, 1980.

GREGORY, K. E.; LUNSTRA, D. D.; CUNDIFF, L. V.; $\mathrm{KOCH}, \mathrm{R}$. M. Breed effects and heterosis in advanced generations of compoite populations for puberty and scrotal traits of beef cattle. Journal Animal Science, Champaign, v. 69, n. 7, p. 2795-2807, 1991.

KOURY FILHO, W.; ALBUQUERQUE, L. G.; ALENCAR, M. M.; FORNI, S.; VASCONCELOS SILVA, J. AII.; LÔBO, R. B. Estimativas de herdabilidade e correlações para escores visuais, peso e altura ao sobreano em rebanhos da raça Nelore. Revista Brasileira de Zootecnia, Viçosa, MG, v. 38, n. 12, p. 2362-2367, 2009.

KRATZ, L. R.; FIGUEIREDO, L. A.; NARDON, R. F.; CYRILLO, J. N. S. G.; RUGGIERI, A. C. Efeitos de raça e da seleção para peso pós-desmame sobre características de confinamento e de carcaça da $15^{\mathrm{a}}$ progênie dos rebanhos Zebu e Caracu de Sertãozinho (SP). Revista Brasileira de Zootecnia, Viçosa, MG, v. 30, n. 1, p. 115124, 2001.

LAGROTTA, M. R.; EUCLYDES, R. F.; VERNEQUE, R. S.; SANTANA JÚNIOR, M. L.; PEREIRA, R. J.; TORRES, R. A. Relação entre características morfológicas e produção de leite em vacas da raça Gir. Pesquisa Agropecuária Brasileira, Brasília, v. 45, n. 4, p. 423-429, 2010.

LIMA, I. A.; REZENDE, C. A. P. de R.; PAIVA, P. C. de A.; ANDRADE, I. F. de A.; MUNIZ, J. A. M. Condição corporal e características de carcaça de vacas de descarte na região de Lavras-MG. Ciência Agrotécnica. Lavras, v. 28, n. 3, p. 637-646, 2004.

LÔBO, R. N. B.; MARTINS, J. A. M.; MALHADO, C. H. M.; MARTINS FILHO, R.; MOURA, A. A. A. Correlações entre características de crescimento, abate e medidas corporais em tourinhos da raça Nelore. Revista Ciência Agronômica, Fortaleza, v. 33, n. 2, p. 5-12, 2002. 
MENEZES, L. F. G.; RESTLE, J.; KUSS, F.; BRONDANI, I. L.; ALVES FILHO, D. C.; CATELLAM, J.; OSMARI, M. P. Medidas corporais de novilhos das gerações avançadas do cruzamento rotativo entre as raças Charolês e Nelore, terminados em confinamento. Revista Brasileira de Zootecnia, Viçosa, MG, v. 38, n. 3, p. 771777, 2008.

MERCADANTE, M. E. Z.; RAZOOK, A. G.; SILVA, J. A. V.; FIGUEIREDO, L. A. Escore de condição corporal de vacas da raça nelore e suas relações com características de tamanho e reprodução. Archivos Latinoamericanos de Producción Animal, Maracaibo, v. 14, n. 4, p. 143-147, 2006.

MOURÃO, R. C.; RODRIGUES, V. C.; MOUSTACAS, V. S.; COSTA, D. P. B.; PINHEIRO, R. B.; FIGUEIREDO, M.; VIEIRA, A. O. Medidas morfométricas de novilhos castrados Nelore e F1 Nelore x Limousin. Agropecuária Científica no Semi-Árido, Campina Grande, v. 6, n. 1, p. 27-32, 2010.

PACHECO, A.; QUIRINO, C. R.; PINHEIRO, O. L. V. M.; ALMEIDA, J. V. C. Medidas morfométricas de touros jovens e adultos da raça Guzerá. Revista Brasileira de Saúde e Produção Animal, Ondina, v. 9, n. 3, p. 426435, 2008.

PASCOAL, L. L.; LOBATO, J. F. P.; VAZ, F. N.; VAZ, R. Z.; MENEZES, L. F. G. Beef cuts yield of steer carcasses graded according to conformation and weigh. Revista Brasileira de Zootecnia, Viçosa, MG, v. 39, n. 6, p. 1363 1371, 2010.

PEREIRA, L. P.; RESTLE, J.; BRONDANI, I. L.; ALVES FILHO, D. C.; SILVA, J. H. S.; MUEHLMANN, L. D. Desenvolvimento ponderal de bovinos de corte de diferentes grupos genéticos de Charolês x Nelore inteiros ou castrados aos 8 meses de idade. Ciência Rural, Santa Maria, v. 30, n. 6, p. 1033-1039, 2000.

PEREIRA, M. C.; YOKOO, M. J.; BIGNARDI, A. B.; SEZANA, J. C.; ALBUQUeRQUE, L. G. Altura da garupa e sua associação com características reprodutivas e de crescimento na raça Nelore. Pesquisa Agropecuária Brasileira, Brasília, v. 45, n. 6, p. 613620, 2010.

PEROBELLI, Z. V.; RESTLE, J.; MÜLLER, L. Estudo das carcaças de vacas de descarte Charolês e Nelore. Pesquisa Agropecuária Brasileira, Brasília, v. 30, n. 36, p. 409-412, 1995.

PEROTTO, D.; ABRAHÃO, J. J. S.; MOLETA, J. L. Características quantitativas de carcaça de bovinos Zebu e de cruzamentos Bos Taurus x Zebu. Revista Brasileira de Zootecnia, Viçosa, MG, v. 29, n. 6, p. 2019-2029, 2000.
PILAU, A.; LOBATO, J. F. P. Desenvolvimento e desempenho reprodutivo de vacas primíparas aos 22/24 meses de idade. Revista Brasileira de Zootecnia, Viçosa, MG, v. 38, n. 4, p. 728-736, 2009.

RESTLE, J.; FELTEN, H. G.; VAZ, F. N. Efeito de raça e heterose para desempenho em confinamento de novilhos de corte. In: REUNIÓN LATINOAMERICANA DE PRODUCCIÓN ANIMAL, 14., 1995, Mar del Plata. Memórias... Balcarce: ALPA, 1995. v. 3-4, p. 852-854.

RESTLE, J.; PASCOAL, L. L.; FATURI, C.; ALVES FILHO, D. C.; BRONDANI, I. L.; PACHECO, P. S.; PEIXOTO, L. A. O. Efeito do grupo genético e da heterose nas características quantitativas da carcaça de vacas de descarte terminadas em confinamento. Revista Brasileira de Zootecnia, Viçosa, MG, v. 31, n. 1, p. 350362, 2002. Suplemento.

RESTLE, J.; POLLI, V. A.; SENNA, D. B. Efeito de grupo genético e heterose sobre a idade e peso a puberdade e sobre o desempenho reprodutivo de novilhas de corte. Pesquisa Agropecuária Brasileira, Brasília, v. 34, n. 4, p. 701-707, 1999 b.

RESTLE, J.; POLLI, V. A.; SENNA, D. B.; VAZ, R. Z.; SILVA, J. H. S. Desenvolvimento de bovinos de corte de diferentes grupos genéticos desmamados aos 3 ou 7 meses de idade. Revista Brasileira de Zootecnia, Viçosa, MG, v. 28, n. 5, p. 1023-1030, 1999a.

RESTLE, J.; VAZ, F. N.; FEIJO, G. L. D.; BRONDANI, I. L.; ALVES FILHO, D. C.; BERNARDES, R. A. C. L.; FATURI, C.; PACHECO, P. S. Características de carcaças de bovinos de corte inteiros ou castrados de diferentes composições raciais charolês x Nelore. Revista Brasileira de Zootecnia, Viçosa, MG, v. 29, n. 5, p. 1371-1379, 2000.

RESTLE, J.; VAZ, F. N.; ROSO, C.; OLIVEIRA, A. N.; CERDÓTES, L.; MENEZES, L. F. G. Desempenho e características da carcaça de vacas de diferentes grupos genéticos em pastagem cultivada com suplementação energética. Revista Brasileira de Zootecnia, Viçosa, MG, v. 30, n. 6, p. 1813-1823, 2001.

REZENDE, P. L. P. de; RESTLE, J.; FERNANDES, J. J. L.; PÁDUA, J. T.; FREITAS NETO, M. D. de; ROCHA, F. M. Desempenho e desenvolvimento corporal de bovinos mestiços submetidos a níveis de suplementação em pastagem de Brachiaria brizantha. Ciência Rural, Santa Maria, v. 41, n. 8, p. 1453-1458, 2011.

ROCHA, E. D.; ANDRADE, V. J.; EUCLIDES FILHO, K.; NOGUEIRA, E.; FIGUEIREDO, G. R. Tamanho de vacas Nelore adultas e seus efeitos no sistema de produção de gado de corte. Arquivos Brasileiros de Medicina Veterinária e Zootecnia, Belo Horizonte, v. 55, n. 4, p. 474-479, 2003. 
ROSA, A. N.; LOBO, R. B.; OLIVEIRA, H. N.; BORJAS, A. R. Variabilidade genética do peso adulto de matrizes em um rebanho Nelore do Estado de São Paulo. Revista Brasileira de Zootecnia, Viçosa, MG, v. 29, n. 6, p. 1706-1711, 2000.

SOUZA, J. C.; MALHADO, C. H. M.; SILVA, L. O. C.; FERRAZ FILHO, P. B. Efeito do ambiente sobre o peso de bovinos da raça Guzerá no estado de São Paulo. Archives of Veterinary Science, Curitiba, v. 7, n. 1, p. 57- 63, 2002.

VAZ, R. Z.; LOBATO, J. F. P.; RESTLE, J. Productivity and efficiency of cow herds submitted to two weaning ages. Revista Brasileira de Zootecnia, Viçosa, MG, v. 39, n. 8, p. 1849-1856, 2010.

VAZ, R. Z.; RESTLE, J.; VAZ, M. B.; PASCOAL, L. L.; VAZ, F. N.; BRONDANI, I. L.; ALVES FILHO, D. C.; MIRANDA, J. N. Desempenho de novilhas de corte até o parto recebendo diferentes níveis de suplementação durante o período reprodutivo, aos 14 meses de idade. Revista Brasileira de Zootecnia, Viçosa, MG, v. 41, n. 3, p. 797-806, 2012.
VIEIRA, H. C. M.; FREITAS, M. A. R.; LÔBO, R. B.; ZAMBIANCHI, A. R.; BEZERRA, L. F.; OLIVEIRA, J. A. Evolução das características de crescimento em rebanhos da raça Guzerá participantes de programa de melhoramento genético. In: SIMPÓSIO DA SOCIEDADE BRASILEIRA DE MELHORAMENTO ANIMAL, 5, 2004, Pirassununga. Anais... Pirassununga: Sociedade Brasileira de Melhoramento Animal, 2004. p. 1-3.

YOKOO, M. J.; LOBO, R. B.; ARAUJO, F. R. C.; BEZERRA, L.A. F.; SAINZ, R. D.; ALBUQUERQUE, L. G. Genetic associations between carcass traits measured by real-time ultrasound and scrotal circumference and growth traits in Nellore cattle. Journal of Animal Science, Champaign, v. 88, n. 1, p. 52-58, 2010. 